\title{
The influence of football players' credibility on consumers' loyalty commitment to a football club
}

\author{
A.Z. Qashri \& Y. Alversia \\ Master of Management, Faculty of Economics and Business, Universitas Indonesia, Indonesia
}

\begin{abstract}
The purpose of this research is to examine the impact of football players' credibility on consumers' loyalty commitment to a football club, particularly in Indonesia. The research involved a specific football club, Madura United FC. Data were collected by distributing questionnaires $(n=1,388)$ to Madura United FC fans and were analyzed using SEM-PLS. The findings indicated that trustworthiness in a football player plays a great role in increasing both brand credibility and attitude of a football club. Brand credibility of a football club proved to be a significant factor affecting fans' loyalty commitment to a football club. This research provides insights into football clubs, particularly on the importance of achieving high brand credibility for achieving fans' loyalty commitment toward a football club.
\end{abstract}

\section{INTRODUCTION}

Football is one of the most well-known sports in the world. According to a study conducted by Terrel et al. in 2005, the number of football fans around the world had reached billions and the numbers were steadily increasing over time (Terrel et al., 2005). Moreover, sports are product-led, which means that what happens in a game or a match is what gives strength to the product (Chadwick, 2017), and what happens in a game relies completely on the team. Hence, the main asset of a football club is its players. Yu (2005) argued that athlete's good performance and positive image has a significant effect on building a successful brand and an endorsement, thus making athletes an important asset for a club, not only because of their technical skills and contribution to the club's performance in a competition, but also as an advantage to use their image for marketing purposes (Castillo, 2007).

This research focuses on the Indonesian football market, specifically Madura United FC. Madura United FC is a relatively young club that was established back in 2016, but has gained many followers and fans, since the city had never experienced having a professional football club representing its area. Considering that there has been currently minimum research on the marketing value that an athlete brings to the stakeholders of a football club, this research is significant for the football industry because it aims at investigating which characteristic in an athlete that will bring the most benefit to football clubs. Moreover, this research also aims at finding out the influence of a football club's credibility and attitude to fans' loyalty commitment.

\section{LITERATURE REVIEW}

\subsection{Football players as an endorser of a football club}

An identification of a target group is often influenced by an individual's identification with an associated group, when the target group is perceived to represent the group (Heere et al., 2011). If a consumer is attached to a human brand, it offers a significant potential for endorsers (Thomson, 
2006). Thus, professional athletes in sports are direct endorsers of their respective teams (Carlson \& Donovan, 2013). Athletes also represent an important brand association for their team (Gladden \& Funk, 2002), where sports teams are strongly linked to their personalities inside the team compared to other brands (Smith et al., 2006).

\subsection{Football club as a brand}

Like retail brands, football clubs brand themselves the way they would like to be perceived. Branding in a football club creates a point of differentiation and individuality, provides a motive for people to buy or consume the products, and provides a chance for consumers to be more loyal to a brand. The most important outcome of branding for football clubs is that it leads to brand equity; in which, equity in football's case may be built by team-related factors such as quality and credibility of players that a football team possess (Chadwick, 2017).

\subsection{The source credibility model}

The source credibility model contends that a message's effectiveness depends on the perceived level of expertise, trustworthiness, and attractiveness in an endorser (Hovland \& Weiss, 1951). Expertise is defined as the skills and the historical performance of the players. Trustworthiness is the attitude of dignity, believability, and honesty possessed by the endorser as observed by the consumer (Erdogan, 1999). Attractiveness is something that creates a positive effect on the brand credibility and brand attitude (Erdogan, 1999; Wang et al., 2016), where brand credibility is defined as believability of the information produced by a brand (Erdem \& Swait, 2001), and brand attitude is the defined as summary of evaluation of a particular brand that influences behavior (Spears \& Singh, 2004).

H1: Consumer's attitude of a club's players, which includes attractiveness (H1a), trustworthiness (H1b), and expertise (H1c), positively influences the club's brand credibility.

H2: Consumer's attitude of a club's players, which includes attractiveness (H2a), trustworthiness $(\mathrm{H} 2 \mathrm{~b})$, and expertise (H2c), positively influences the club's brand attitude.

Sweeney and Swait (2008) stated that there is a positive effect of brand credibility on loyalty commitment. Loyalty commitment reflects an emotional and positive sentiment of the customer toward the idea of staying in the firm's customer base (Sweeney \& Swait, 2008). Moreover, brand attitude has been proven to positively affect loyalty, and brand loyalty is essentially based on positive brand attitude, brand trust, and brand affective commitment (Gomez \& Rubio, 2010).

H3: Brand credibility positively influences loyalty commitment.

H4: Brand attitude positively influences brand attitude.

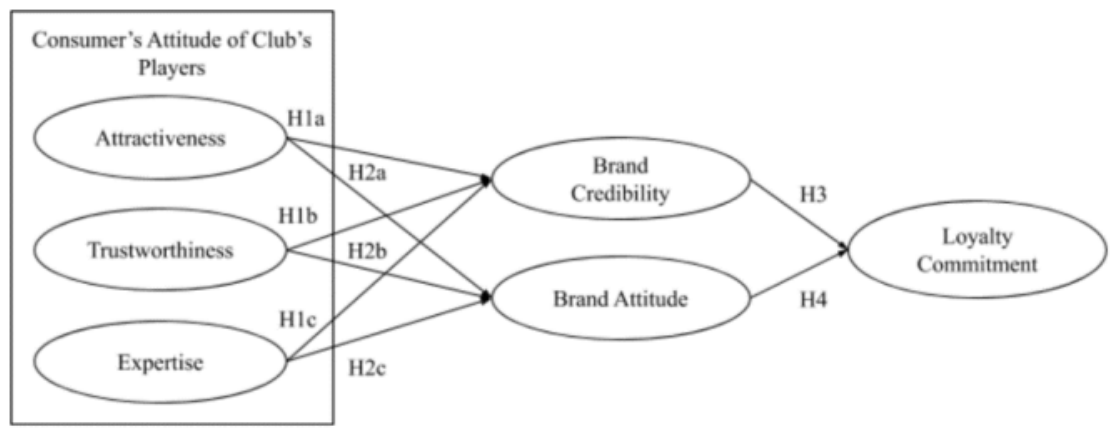

Figure 1. Conceptual model. 


\section{METHOD}

Data were collected through questionnaires that were distributed on social media. One screening question was placed in the beginning of the questionnaire to prevent non-fans to fill in the questionnaire. Among 1,388 respondents, 1,379 respondents were Madura United FC fans, and thus, 1,379 answers were further analyzed. Most of the respondents (47.3\%) were 10-20 years old, and $73.2 \%$ of them resided in East Java, Indonesia. Moreover, most of the respondents (79.2\%) have been a fan of Madura United FC for more than 2 years, and $50.6 \%$ of respondents have bought an official merchandise from Madura United FC at some point. $85.8 \%$ of respondents have watched a live match featuring Madura United FC in a stadium, and $38.7 \%$ of them have watched a live match for less than 10 times.

Each of the consumer's attitude of club players' dimension used three indicators and were formed using a six-point scale to avoid neutral answers (Wang et al., 2017). Brand credibility, brand attitude, and loyalty commitment also used three indicators formed using a six-point scale (Sweeney \& Swait, 2008).

\section{RESULTS}

This research used PLS-SEM to examine the causal relationships between variables (Garson, 2016). Most of the hypotheses were supported, except for $\mathrm{H} 1 \mathrm{c}(\mathrm{O}=0.002$, T Statistics $=0.066$, $\mathrm{P}$-Value $=0.471)$ and $\mathrm{H} 2 \mathrm{c}(\mathrm{O}=-0.026$, T Statistics $=0.721$, P-Value $=0.471)$, and both explain the relationship of expertise with both brand credibility $(\mathrm{H} 1 \mathrm{c})$ and brand attitude $(\mathrm{H} 2 \mathrm{c})$. Attractiveness was concluded to have a significant effect on both brand credibility $(\mathrm{H} 1 \mathrm{a})(\mathrm{O}=0.142$, $\mathrm{T}$ Statistics $=4.122, \mathrm{P}-$ Value $=0.00)$ and brand attitude $(\mathrm{H} 2 \mathrm{a})(\mathrm{O}=0.145$, T Statistics $=3.720$, $\mathrm{P}-$ Value $=0.00)$. Moreover, both brand credibility $(\mathrm{H} 3)(\mathrm{O}=0.436$, T Statistics $=8.293$, PValue $=0.00)$ and brand attitude $(\mathrm{H} 4)(\mathrm{O}=0.193$, T Statistics $=3.518, \mathrm{P}$-Value $=0.00)$ were concluded to have a positive and significant relationship with loyalty commitment.

\section{DISCUSSION}

Attractiveness and trustworthiness had a positive and significant effect on brand credibility and brand attitude, and trustworthiness most aptly explains both brand credibility and brand attitude compared to the two other variables of attractiveness and expertise. Expertise was the variable that least affected both brand credibility and brand attitude. To explain this result, a football team is considered as an icon and representation of a local area (Van Houtum \& Van Dam, 2002). A fan is defined as an individual with a lasting connection to a particular subject (Thorne \& Bruner, 2006). It means that a football fan's demographic location might influence fan fanaticism. Furthermore, fan loyalty creates a constant patronage even when the team fails to produce solid results on the field (Gladden \& Funk, 2002). This means that even in the absence of expertise, fans might still show a positive behavior toward the team they support.

Both brand credibility and brand attitude have a positive and significant effect to loyalty commitment. This is in accordance with previous studies that successfully proved that high brand credibility and positive brand attitude will lead to an increase in loyalty commitment to a brand (Sweeney \& Swait, 2008; Gomez \& Rubio, 2010)

\section{CONCLUSION AND IMPLICATION}

This study aims at examining the relationship of a consumer's attitude of a club's player (which includes attractiveness, expertise, and trustworthiness of a player) with fans' loyalty commitment to a football club. The results indicated that in order for football clubs to reach a higher level of 
brand attitude and brand credibility, the management of a football club should consider choosing a trustworthy and an attractive football player. Interestingly, expertise of a player has an insignificant relationship with both brand credibility and brand attitude. This result should be interpreted with extra caution, since team performance, which is directly influenced by individual expertise, is one of the most determining factors for the team's success (Chappelet et al., 2017).

In order to increase fans' loyalty commitment toward a club, its management should focus on increasing the club's credibility by being consistent in their service quality, pricing, promotion, and their channels, including communication with customers (Sweeney \& Swait, 2008).

\section{REFERENCES}

Carlson, Brad D. 2013. Human brands in sport: Athlete brand personality and identification. Journal of Sport Management. 27(3): 193-206.

Castillo, J.C. 2007. The concept of loyalty and the challenge of internationalization in post-modern Spanish football. International Journal of Iberian Studies, 20(1): 23-40.

Chadwick, S. 2017. Handbook of Football Association Management (3): 117-138. Nyon: UEFA Education Programme.

Chappelet, J. \& Aquilina, D. 2017. Handbook of Football Association Management. Nyon: UEFA Education Programme.

Erdem, T., Swait, J. 2001. Brand equity as a signalling. J. Consumer Psychol. 7(2): 131-157.

Erdogan, B.Z. 1999. Celebrity endorsement: a literature review. J. Mark. Manag. 15(4).

Garson, G. D. 2016. Partial Least Squares: Regression and Structural Equation Models. Statistical Associates Publishers.

Gladden, J.M. \& Funk, D.C. 2002. Understanding brand loyalty in professional sport: examining the link between brand associations and brand loyalty. International Journal of Sports Marketing and Sponsorship. 3(1).

Gómez, M. \& Rubio, N. 2010.Re-thinking the relationship between store brand attitude and store brand loyalty: a simultaneous approach. The International Review of Retail, Distribution and Consumer Research. 20(5): $515-534$.

Heere, B., James, J.D., Yoshida, M., \& Scremin, G. 2011. The effect of associated group identities on team identity. Journal of Sport Management 25: 1-44.

Hovland, C.I. \& Wiess, W. 1951. The influence of source credibility on communication effectiveness. Public Opin. Q. 15 (4).

Smith, A., Graetz, B.R. \& Westerbeek, H.M. 2006. Brand personality in a membership-based organization. International Journal of Nonprofit and Voluntary Sector Marketing, 11(3): 251-266.

Spears, N. \& Singh, S. N. 2004. Measuring Attitude toward the Brand and Purchase Intentions. Journal of Current Issues \& Research in Advertising. 26(2): 53-66.

Sweeney, J. \& Swait, J. 2008. The Effects of Brand Credibility on Customer Loyalty. Journal of Retailing and Consumer Services. 15(3).

Terrel, E., Herd, J., Marcus, L., Sams, J. \& Sullivan, J. 2005. The Business of Soccer. Retrieved 16 May 2020 from: http://www.loc.gov/rr/business/BERA/issue3/soccer.html

Thomson, M. 2006. Human brands: Investigating antecedents to consumers' strong attachments to celebrities. Journal of Marketing (70): 104-119.

Thorne, S. \& Bruner, G.C. 2006. An exploratory investigation of the characteristics of consumer fanaticism. Qualitative Market Research: An International Journal. 9(1): 51-72

Van Houtum, H. \& Van Dam, F. 2002. Topophilia or topoporno? Patriotic place attachment in international football derbies. International Social Science Review. 3 (2): 231-248.

Wang, S. W, Kao, G.H.S. \& Ngamsiriudom, W. (2017). Consumers' Attitude of Endorser Credibility, Brand and Intention with Respect to Celebrity Endorsement of the Airline Sector. Journal of Air Transport Management. 60: $10-17$.

Yu, C. 2005. Athlete endorsement in the international sports industry: a case study of David Beckham. International Journal of Sports Marketing and Sponsorship, 6(3): 189-199. 